As it turns, the radiating bars on it are brought to a vertical position one after the other; and, while passing this position, they raise the lever suspended above, and, by the action of the pin at its end, keep the circuit open. They are so placed and gauged that they hold the rircuit open from 55 to 60 seconds of the first, and then of the second minute.

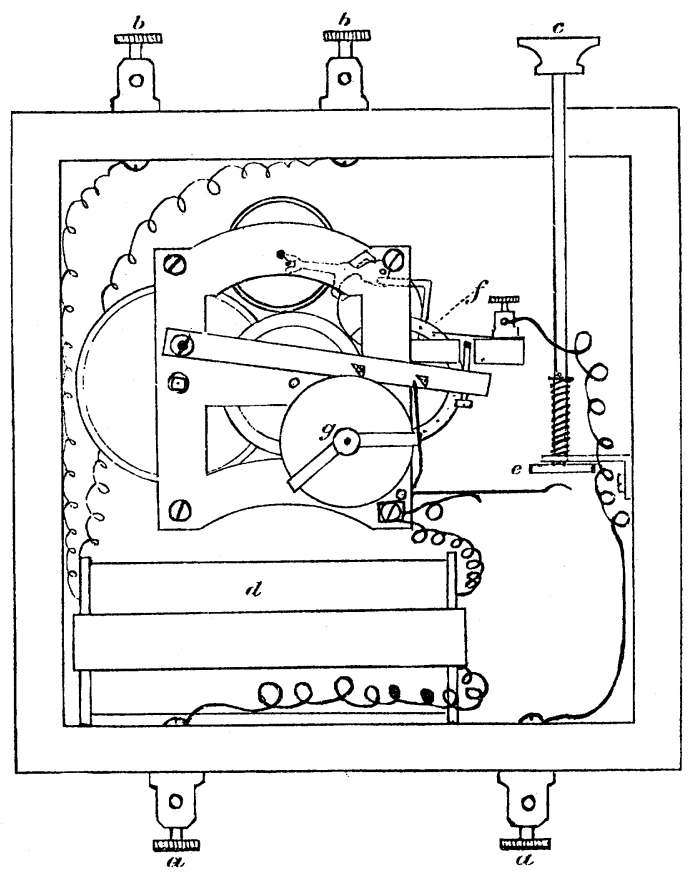

FIG. 2.

Each break in the primary circuit causes a distinctly audible sound in the ear-telephone. This sound is so loud that I have sometimes heard it across the room. As the circuit is broken each second for the first fifty-five seconds of each full minute, and for the full thirty of the last half-minute, the time-transmitter gives a series of seconds signals easily received at any telephone in connection with it. The intermission of five seconds at the end of each full minute serves to notify the receiver that the next minute is about to begin, and thus saves him the trouble of counting.

In using the time-transmitter, the person who desires the time calls me up by telephone, and I start the transmitter at the beginning of some minute by his time. 'The correspondents are usually jewellers, and do not need to be told the minute at which the transmitter began. If they do need the minute, it can be given them verbally by the Blake transmitter. The suc- cession of beats and intermissions gives the receiver four opportunities for comparison; viz., the beginning of the first, second, and third minute, and the end of two minutes and a half.

An important feature of this method is its capacity for transmitting time to several or many persons simultaneously. In order to test this, Manager Keech of this place obligingly called up all the exchanges connected with us. Some did not respond; but those who did - a dozen or fifteen in number, and distant in all directions from ten to seventy-five miles from us - all heard the beats of the transmitter distinctly, except at Port Huron. From this and some other tests, I concluded, that, by this method, the time could be received by at least twentyfive telephones simultaneously.

M. W. Harrington.

\section{PARENTAL INSTINCT AS A FACTOR IN THE EVOLUTION OF SPECIES.}

Is a recent lecture at the Sheffield scientific school, New Haven, the writer called attention to the lack of maternal care as one of the probable causes, though usually overlooked, of the extinction of many of the large and powerful reptiles of the mesozoic age, and of the large mammals of the tertiary. The very small size of the brain and its low organization, in these early animals, are now well known, and we are justified in believing that their intelligence or sagacity was correspondingly low. They were doubtless stupid and sluggish in their habits, but probably had great powers of active and passive resistance against correspondingly stupid carnivorous species. But, unless the helpless young were protected by their parents, they would quickly have been destroyed; and such species might, in this way, have been rapidly exterminated whenever they came in contact with new forms of carnivorous animals, having the instinct to destroy the new-born young of mammals, and the eggs and young of oviparous reptiles.

Thus it would have come about, that the more intelligent forms, by the development of the parental instinct for the active protection of their young against their enemies, would have survived longest, and therefore would have transmitted this instinct, with other correlated cerebral developments, to their descendants. This mode of natural selection must always have been a very active one, wherever carnivorous mammals, birds, and reptiles, have existed in contact with herbivorous species. 
Moreover, such Carnivora, among modern species, will also devour the eggs and young of other Carnivora. Therefore the development of equally strong parental instincts in the Carnivora themselves would have come about in the same way. It is evident, that, in this manner, carnivorous animals of comparatively small size may have been the means of exterminating the largest and most powerful beasts and reptiles.

Among nearly all of the existing mammals and birds, the parental instinct is very remarkably developed in one or both sexes, usually more so in the female. Many species, now abundant, would soon become extinct if the parents did not have remarkable sagacity in protecting their young against numerous enemies. Many reptiles, fishes, insects, and still lower forms, also show wonderful maternal instincts. We cannot suppose that their ancient allies had these instincts in the same way, nor to the same extent. In many cases the enemies to be protected against are of comparatively modern origin. New modes of parental protection must, therefore, have been developed or acquired as new enemies appeared. The ways in which different species protect their young are exceedingly varied, as all naturalists know ; and many areas wonderful as any habits known among the lower animals.

The development of the powerful parental instinct for the protection and care of the young, in the earliest races ${ }^{\circ}$ of man, must have been of vital importance in man's struggle for existence in his primitive and comparatively helpless condition.

In fact, it is evident, that without this strong impulse, and the intelligence necessary to make it effective, neither man, nor any of the species of mammals belonging to the higher orders, could have existed, even for a short period.

Possibly the variations in the degree of development of the parental care, in different races of man, may be connected with the increase of some races and the extinction or decline of others.

\section{A. E. Verrill.}

\section{LAKES AND VALLEYS IN NORTH- EASTERN PENNSYLVANIA.}

H. D. RogERs, many years ago, pointed out the connection between the lakes and the northern drift in Pennsylvania. In a recent report of the second geological survey, ${ }^{1} \mathrm{Mr}$. White gives fuller information on this interesting question, and shows that

1 G. 6. Geology of Pike and Monroe Counties, by I. C. White; Special surveys of the Delaware and Lehigh Water-gaps, by H. M. Chance. Harrisburg, 1882. the numerous ponds north of the Delaware Watergap (forty-two are enumerated) are generally held in either drift-barrier or drift-enclosure basins, though the depth of some of them seems partly dependent on local erosion in soft shale. The largest is about two square miles in area, and nearly all are less than forty feet in depth. Their shape is generally round or oval; but Long Lake, a narrow expansion of Tunkhannock Creek, three miles long, is an exception to the rule; and, unlike the others, it stands just outside the so-called 'terminal moraine,' or margin of the glaciated area. Glacial action is not regarded as having effected great destructive changes in the preexisting topography, except in the way of "pushing or disrupting' rocks that were divided into blocks by joints. The corniferous limestone, especially, has suffered in this way; and its great bowlders, 'many of them as large as a good-sized house,' are strewn beyond its outcrop over a scored and polished surface of cauda-galli grit. It would be interesting to learn if such corniferous bowlders are limited to the glaciated district, and do not occur farther south as a result of simple weathering. All the larger valleys of this region contain modified drift, on which the streams flow without reaching the rocky bottom. In the Delaware and Lehigh valleys, this drift extends far beyond the limits of glacial action; but in the Schuylkill valley, which heads outside of the glaciated area, it is absent altogether (p. xvii.). At and above the Delaware Water-gap, the rocky channel is filled with drift to a depth of probably one hundred feet. All the line of outcrop of the Marcellus shale, from north of Rondout, N.Y., past Port Jervis, where the Delaware joins and flows along it, even beyond Stroudsburg, a distance of ninety miles, is an old, wide, deep valley, buried in stratified drift; but on passing out of the glaciated area, just south of Sciota, some distance after the Delaware turns southward through its gap, the same weak shale is occupied by a valley less than a tenth of its former width. It is therefore suggested that this buried valley was cut by streams under the ice of glacial times.

Narrow post-glacial channels of moderate length, cut in the rock by streams turned from their open pre-glacial valleys by drift-obstruction, are found at several points. The drift-filling of the old Sawkill is as much as three hundred feet deep; and the falls on its new channel are a result and mark of its recent adoption. Raymondskill Falls have the same cause. The Wallenpaupack takes a short cut of two miles, instead of following its old path of four miles, to the Lackawaxen, and, on its new course, has eroded a gorge seventy-five feet deep, ending in falls with a total descent of two hundred and sixty feet in a mile. Above the gorge, the stream meanders for ten miles over a broad, marshy flat, falling only half a foot to a mile, - the final stage of a lake that must have existed in the obstructed valley till the cutting of the gorge drained it. It is very plausibly suggested that all the cascades of this district "owe their origin to a similar diversion of their streams by the driftdams thrown across their pre-glacial channels;" and we believe that this cause of gorge, ravine and cascade has a very general application in glaciated countries.

The greater part of the report following these introductory pages is devoted to a detailed description of the geological formations of the district.

Mr. Chance's surveys of the Delaware and Lehigh Water-gaps, in the same report, include fine illustration of these notable cross-valleys in contour-line maps and vertical sections; but their description is chiefly geological. It may be noted, that the disloca- 